w Poznaniu

krypien@amu.edu.pl

\title{
„Kao misnik" i „kao Turci iz Smail-age”. Funkcja pokarmów w nowoczesnej i ponowoczesnej narracji Lepszej polowy odwagi Ivana Slamniga
}

Abstract: Pieniążek-Marković Krystyna, , Kao misnik” i „,kao Turci iz Smail-age”. Funkcja pokarmów w nowoczesnej i ponowoczesnej narracji Lepszej połowy odwagi Ivana Slamniga („,Kao misnik" i „kao Turci iz Smail-age”. A Function of Food in the Modern and Postmodern Narration of The Better Half of Courage by Ivan Slamnig). "Poznańskie Studia Slawistyczne" 13. Poznań 2017. Publishing House of the Poznan Society for the Advancement of the Arts and Sciences, pp. 109-128. ISSN 2084-3011.

In the novel entitled The Better Half of Courage, Ivan Slamnig elaborates on two types of narrative namely, a traditional internal story derived from the poetics of realism and a postmodern frame story streaked with the elements of the jeans prose. In the article, culinary motifs presented in both narratives are taken into consideration in order to expose their function in Slamnig's novel. The article also tries to answer the question whether the dietary code is subordinated to the both forms of discourse. The analysis of the culinary themes reveals a process of braking off with tradition in the so-called traditional narrative, and attempts of retaining tradition in the postmodern narrative. In consequence, an apparently traditional modern pilgrim, who does not respect the order of traditional rituals and remains cautious in his consumption behaviour, turns out to be condemned to painful results of his choices while a postmodern vagrant as an unfulfilled consumer-glutton keeps drawing from tradition as well as from the present day what provides him with various pleasures. Furthermore, the analysis of the culinary code of the novel allows the authoress to confirm a thesis on the presence of postmodern effects in the both "parts" of the novel.

Keywords: food, Croatian literature, liminal rites, gluttony, guardedness

Lepsza połowa odwagi, jedyna (mikro)powieść Ivana Slamniga, czołowego reprezentanta pokolenia krugovców, uznawana jest za klasyczną realizację jeans prozy (Flaker, 1983) oraz za jedno z pierwszych chorwackich postmodernistycznych dzieł prozatorskich (cf. np. Milanja, 1996, 2001; Nemec, 2003; Jukić, 2006; Małczak, 2007; Tadić-Šokac, 2009; 
Grgić, 2010). Slamnig na różnych poziomach utworu stosuje zabiegi intertekstualne, intermedialne, metatekstualne, metafikcjonalne, autoreferencjalne, ludyzm, miesza kody literatury niskiej i wysokiej, prowadzi dialog z tradycją i historią. W tym celu wykorzystuje także szkatułkową budowę, która pozwala rozwijać dwa typy narracji: ponowoczesną (realizowaną w opowieści ramowej) i nowoczesną (stosowaną w opowieści wewnętrznej). Mówię tutaj o schematycznym podziale na opowieść tradycyjną i postmodernistyczną, który - jak pokaże dalszy wywód - nie jest tak oczywisty i nie pozwala utrzymać jednoznacznego wstępnego rozpoznania. Akcja historii ramowej usytuowana jest w Zagrzebiu i Zagorju w latach 70. XX w., a jej narratorem i głównym bohaterem jest Flaks, mężczyzna w średnim wieku, pisarz, tłumacz, badacz przygotowujący rozprawę o zabytkowych napisach w Chorwacji północnej pt. Preobrazba književnog i saobraćajnog jezika u sjevernoj Hrvatskoj u 19. stoljeću. Wydarzenia historii wewnętrznej dotyczą Dalmacji lat 30. i 40. XX w., a jej autorką jest bohaterka opowieści ramowej, starsza pani (i stara panna) Matylda, opisująca losy młodej dziewczyny, a następnie żony i wdowy, Any. Opowieść wewnętrzna ma cechy love story, natomiast ramowa - detective story (cf. Tadić-Šokac, 2009, 107-110). Matylda opowiada miłosną historię Any i Vojka, która ma być środkiem służącym zdobyciu sympatii Flaksa (wyznaniem miłosnym), natomiast Flaks zamienia się w detektywa, usiłującego odgadnąć sens opowiadania Matyldy (jest też poszukiwaczem zabytków piśmiennictwa i różnorodnych przygód).

Zajmujące postmodernistyczne elementy struktury powieści zostały już dość wnikliwie opisane w literaturze przedmiotowej. Celem niniejszego artykułu jest analiza funkcji, jaką w tej literackiej realizacji pełni kod kulinarny, poszukiwanie odpowiedzi na pytanie, czy wątki dotyczące jedzenia podporządkowane są formom obu dyskursów: nowoczesnego, realistycznego w swych założeniach ${ }^{1}$, miłosnego dyskursu opowieści we-

${ }^{1}$ Tak najczęściej w literaturze przedmiotowej klasyfikowana jest tradycyjna narracja wewnętrzna Slamniga, ale jej ,autorka”, ciotka Matylda, deklarująca, że pisze na podstawie przeczytanych lektur, zna nie tylko literaturę dziewiętnastowieczną, lecz także najnowszą. Jej ontologia tekstu literackiego jest jakby wyjęta z postmodernistycznych teorii: [Wychodzę - K.P.-M.] „od postojećih knjiga. Onih koje sam pročitala, naravno. Čini mi se da među gotovim djelima ima još mjesta da se napiše još koje, a ako se počne od toga da je književnost jednoga naroda, pa možda čak i evropska, cjelina s mnogobrojnim organskim vezama, onda 
wnętrznej, z charakterystycznym światopoglądem i poetyką oraz ponowoczesnego dyskursu detektywistycznej opowieści ramowej, czy może język pokarmów wiedzie do konstatacji o przemieszaniu elementów nowoczesnych i ponowoczesnych w obu narracjach.

Kuchnia uznawana jest za rodzaj mowy informującej o strukturze społeczeństwa (Lévi-Strauss, 2008, 63) oraz za wyraz jego kultury (Kirshenblatt-Gimblett, 1999). Warto zatem przeanalizować, jak przedstawiają się widziane poprzez kuchnię kultury społeczeństwa w „obu połowach” Lepszej połowy odwagi oraz jak jedzenie funkcjonuje w różnych kontekstach i jakim służy celom. Na podstawie wniosków antropologów czy socjologów, dotyczących roli kodu żywieniowego w społeczeństwie, należy zakładać, że nieustannie obecne w narracji Slamniga kulinaria pełnią ważną funkcję w kreacji obrazu nowoczesnego i ponowoczesnego konsumenta oraz społecznej i kulturowej rzeczywistości. „Podobnie jak seks, spożywanie pokarmu ma zarówno składnik społeczny, jak i biologiczny. Kategorie pokarmowe kodują zatem wydarzenia społeczne" (Douglas, 2007, 335). Zgodnie z postępowaniem Mary Douglas, która analizuje serię wydarzeń społecznych zakodowanych w rodzinnych posiłkach jej domu, refleksji zostaną poddane serie wydarzeń społecznych zakodowane w posiłkach rodzinnych Any i Vojka oraz posiłkach Flaksowej „rodziny” - klapy ${ }^{2}$. Jedzenie jest rzeczywistością społeczną, ale także szczególną rzeczywistością kulturową i to zarówno ze względu na składniki pożywne, jak i na sposób konsumpcji i towarzyszące jej okoliczności (Montanari, 2011, 113), dlatego również te aspekty kodu kulinarnego powieści Slamniga będą przedmiotem mojego zainteresowania.

se novo djelo može uklopiti među postojeća" (Slamnig, 1998, 300), a przy tym - zdaniem bohaterki - utwór nie musi opisywać rzeczywistości (materiał można bowiem czerpać z historii i dokumentalnych zapisów), bazować na doświadczeniach twórcy ani odpowiadać na upodobania odbiorcy. Matylda stawia zatem postmodernistyczne tezy o autonomii literatury, (nie)oryginalności, intertekstualności. Zamiast dążenia do oryginalności bohaterka-autorka eksponuje potrzebę sprawności zawodowej (Slamnig, 1998, 301).

${ }^{2}$ Termin klapa w kontekście jeans prozy można tłumaczyć jako „paczka” (chodzi o zamkniętą grupę przyjaciół), jednak jego znaczenie pierwotne to grupa wokalna wykonująca tradycyjne śpiewy dalmatyńskie. 


\section{Szprycery, winiaki, rakije}

O tym, że konsumpcja pełni istotną funkcję w utworze, świadczą choćby jego pierwsze sceny - najpierw na parking, na którym zatrzymał się Flaks, podjeżdża ciężarówka z piwem, następnie bohater wchodzi do przesyconej dymem i zapachem gulaszu gospody „Pod dwoma bażantami”. Tam spotyka kolegów ze szkoły, zgromadzonych wokół szprycera. Kiedy sam wybiera winiak, towarzystwo namawia go na przejście na szprycer, co pozwoli przyłączyć się do wspólnoty. W innej sytuacji (podróż do Brestovlja) funkcję integracyjną i komunikacyjną pełni winiak lub miejscowa (brestovaczka) rakija z wytłoczyn winogronowych. Rodzaj alkoholu nie jest zatem istotny, każdy może być wykorzystywany jako środek prowadzący do „zmian w mózgu”, dzięki którym realizowane są funkcje interpersonalne (bliskość i porozumienie) ${ }^{3}$, ważne jednak, by wszyscy uczestnicy biesiady spożywali ten sam trunek. W zatomizowanym i zindywidualizowanym świecie ponowoczesnym konsumpcja pojawia się zatem w jednej ze swych podstawowych funkcji, którą - poza zaspokajaniem głodu i pragnienia - jest jednoczenie wokół stołu. Przypisanie tej roli szprycerowi, który ma także pejoratywne znaczenie (smjesa svega i svačega $a^{4}$, może mieć symboliczną wymowę, sygnalizując charakter relatywistycznej, sceptycznej i pluralistycznej ponowoczesnej rzeczywistości. Alkohol zapewnia również przyjemności: wskazywany jest jako stymulator popędu seksualnego (,Nisam imao želje za Zitom, premda sam je jako volio. Možda, da je još što popiti?”, Slamnig, 1998, 294) oraz środek zapewniający antynomiczny stan ekstatycznego otępienia, które rozumiem jako przyjemność wynikającą z wyłączenia myślenia, uważności („piće me odvelo u ekstatičnu tupost”, Slamnig, 1998, 286; „tępego uniesienia”, Slamnig, 1976, 9).

Również w opowieści Matyldy na wstępie pojawia się motyw gospody i alkoholu (tym razem wino z wodą), z tą różnicą, że konsumenci nie

${ }^{3}$ „Piće i svježi zrak stvarali su nam u mozgu posebno stanje tako da smo brbljali ili čak šutjeli u dužim periodima, tobože kao da razmišljamo ili pažljivo promatramo prirodu, a zapravo smo se grijali na blizini jedno drugoga, i osjećali prirodu više kožom nego očima" (Slamnig, 1998, 315).

${ }^{4} \mathrm{Cf}$. hasło gemišt w drugim znaczeniu, Hrvatski jezični portal, http://hjp.znanje.hr/index.php?show=search. 23.05.2017. 
przesiadują w zadymionym pomieszczeniu, lecz na zewnątrz. Nieco inna jest także funkcja spożywanego trunku i formy picia. Wprawdzie $\mathrm{i} w$ tej opowieści napoje towarzyszą wspólnocie, jednak pite są przede wszystkim w domu, w jego centralnym miejscu, czyli kuchni, przy stole i z wielkim umiarem - matka Any częstuje gości symboliczną kroplą rakiji („suza rakije", s. 310), bywa także, że goście przynoszą do skosztowania własny trunek. Poza jednoczeniem, w opowieści Matyldy wyzyskującej klasyczne schematy narracyjne, alkohol jest wykorzystywany do prezentowania tradycyjnych ról społecznych. W przeciwieństwie do klapy Flaksa, której wszyscy członkowie dzielą prawo (a może nawet obowiązek) uczestniczenia w piciu, Ana, będąc na tańcach, nie dostaje, jak Vojko, białego wina, lecz sok pomarańczowy, pannom bowiem w publicznym miejscu spożywanie alkoholu nie przystało. W narracji Matyldy nie występują pozostałe funkcje spożywania napojów alkoholowych obecne w narracji Flaksa.

\section{Kulinaria $z$ elementarza}

Ponowoczesny konsument, w pokarmach i napojach poszukujący przyjemności, a nie tylko zaspokojenia podstawowych potrzeb fizjologicznych i społecznych, także w kontakcie z zabytkami piśmiennictwa łączy przyjemność lektury z zainteresowaniem kulinariami. W domowej biblioteczce Zyty, przyjaciółki Flaksa, i jej ciotki Matyldy badacz językowej diachronii z satysfakcją odnajduje wiele unikatowych dziewiętnastowiecznych wydań, wśród nich elementarz z 1800 roku, z którego odczytuje fragment dotyczący właśnie jedzenia:

je li jako jelo jetra jelenska?

Od ljuljčenoga kruha ljut, pljuje pljuča, i z ljuljkom pljundre pljuska holovanja Mihalj.

Jeden falačec devenic, s prošenikum jetrenic, rajši neg ptic jarebic hoće Juric Cepec stric.

Friške fanjke na fašenjik filjarka fučkečuč z refom friga.

$\mathrm{K}$ vnogem denes moram iti: $\mathrm{k}$ filjarkam po melju, $\mathrm{k}$ primorcem po sol, $\mathrm{k}$ furlanom po peper. Da ovak k varašu iduča, tak velike kak je najvekša medjimorska rotkva scopam makarune; a makviče pak kakti miholjske tikviče k senjmu mesarom zagrebačkem, za njihovu k Trojakom lepu govedinu z sirotkum i štakorskem salom snažno začinim i k obedu tečno pripravim. (...)

Slanina osmojena i ostro slana jest slatka husarska hrana (Slamnig, 1998, 297). 
Ćwiczenia z elementarza przywołują fundamentalne ludzkie potrzeby życiowe, opisują codzienną troskę o zdobycie pożywienia, upodobania żywieniowe i niepożądane reakcje na spożycie pokarmów niestrawnych lub ciężkostrawnych (jak chleb z ziarna życicy). Konotacje żywieniowe rozciągają się i na inne lekturowe doświadczenia: otrzymany fragment rękopisu Matyldy, mimo że napisany na maszynie, zapachem przypomina bohaterowi czarny inkaust i przyprawy ${ }^{5}$.

\section{Ziemia żywicielka}

Pierwsze „kadry” opowiadanej historii z okresu poprzedzającego II wojnę światową i samej wojny, prezentujące panoramę miasta zamieszkiwanego przez bohaterów i rozciągających się wokół niego pól, zwracają uwagę na „użyteczność” i płodność otaczającej natury: winnice, gaje oliwne, łany kukurydzy i żyta. W narracji Matyldy kilkakrotnie powtarza się motyw ziemi, matki żywicielki, w każdej sytuacji dziejowej znajdującej sposób na wykarmienie swych mieszkańców. Podczas wojennych zmagań z brakiem pożywienia, niespodziewanie natura zaczyna dostarczać obfitych plonów: „More je vrvjelo vrnutima, divlji vinogradi stali su naglo donositi obilan plod" (Slamnig, 1998, 352). Płodnościowy charakter niesprzyjającej przecież uprawom, kamienistej Dalmacji, gdzie toczy się

${ }^{5}$ Gra Slamniga z czytelnikiem polega m.in. na akcentowaniu przestarzałego charakteru narracji Matyldy, którą w modelu prozy dziewiętnastowiecznej chętniej sytuuje Flaks niż ona sama, w swej deklaracji bliska przecież założeniom postmodernizmu (czyli myśleniu samego Slamniga o literaturze, cf. Donat, 1978, 135). Dlatego Flaks „wyczuwa” zapach atramentu, który „,cofa” tekst w odległą przeszłość, oraz zapach przypraw, mogący sugerować, że chodzi o model prozy kobiecej. W obu przypadkach (atrament i przyprawy) doszukiwać się należy sygnałów deprecjonowania. Negatywne wartościowanie wyrażone jest także explicite w porównaniu do dziewiętnastowiecznych pisarzy (tracących cechy indywidualne prozaików i dzieł: „Josipe Eugene Tomiće i Draženoviće, «Turke pod Siskom» i «Pavle Šegote»”, Slamnig, 1998, 299) oraz do Mariji Jurić Zagorki (1873-1957), autorki literatury popularnej, łączącej wątki miłosne z historią, i pierwszej chorwackiej powieści kryminalnej. Tymczasem Matylda podkreśla, że prace typowo kobiece (robótki ręczne) nigdy jej nie interesowały, chętniej porównuje swoje pisarskie zamiłowanie do typowo męskiego zajęcia, którym jest kowalstwo, a pisząc, sięga po najnowsze ,techniki i technologie” (ars combinatoria i maszyna do pisania). Slamnig od początku narracji podważa możliwość (i sensowność) wypełniania luk w dorobku realizmu. 
akcja opowieści o losach Any i Vojka, w szczególny sposób został wyeksponowany przez nawiązanie do symbolu ziemi rodzicielki i karmicielki, która w swym wnętrzu (wnętrznościach) jak w chłodni przechowuje pokarm. Nastawienie do wewnątrz (,,To je svijet sa svojim unutrašnjim težištem”, Slamnig, 1998, 305) jest ściśle związane z zadomowieniem i pielęgnowaniem tradycji ${ }^{6}$.

\section{Jeść, by się rozmnażać}

Do miejscowej tradycji należy konkurowanie w pieczeniu najlepszego ciasta na Boże Narodzenie. Ciotka Any, żona lekarza, zgodnie z obyczajem przygotowuje swoje słynne białe ciasto $^{7}$, natomiast mama Any piecze orahove prutiće, w polskim tłumaczeniu oddane jako neutralne paluszki z orzechami (Slamnig, 1976, 36), jednak - nie tylko kształtem - prutić odsyła do konotacji fallicznych, chorw. prut ('witka') pochodzi z tego samego prasłowiańskiego rdzenia, który w języku polskim dał pręt i prącie. Sam orzech ${ }^{8}$ wzmacnia płodnościowe sensy potraw, symbolicznie odpowiada migdałowi. Tkwiące w nim nasienie zapowiada odrodzenie. Informacja o orzechowych pręcikach układa się w całość z wiadomością, że

${ }^{6}$ Flaks, nomadyczny bohater, w opowieści Matyldy, którą sytuuje w „,czasach dyliżansów”, mimo że dotyczy lat 30. i 40. XX w. (znów gra Slamniga z czytelnikiem, zasadzająca się na jednoczesnym sugerowaniu i podważaniu anachroniczności tradycyjnej narracji), oraz w przyjaźni i romansach z mieszkankami domu Matyldy, Zyty i jej siostrzenicy Anity otrzymuje szansę (ułudę) zakorzenienia i zadomowienia w jakiejś regionalnej arkadii: „Teta me je međutim, sa svojim redovitim nastavcima (...) vezivala uz grudu, pa onda Anita i Zita i naši zajednički izleti, najedanput je u poznatoj, labavo spletenoj sredini nastao nekakav teritorij u kojem sam se ja kretao i bio kod kuće. U toj su zemlji izlazile i periodične publikacije uokvirene u uredan tulac, kao pošta koju razvoze kočije” (Slamnig, 1998, 356). Cf. też Grgić, 2010, 278.

${ }^{7}$ Kolorystycznie odsyłające do lekarskiego kitla; Slamnig wpisuje więc kulinarną narrację w identyfikację zawodową, niestety, zagubioną w polskim przekładzie Aliji Dukanovicia, w której jako ekwiwalent bijelog kolača pojawia się tort śmietankowy (Slamnig, 1976, 36).

${ }^{8} \mathrm{~W}$ tradycji bożonarodzeniowej orzechy obowiązkowo muszą się pojawić na stole; jako nasiona w skorupce związane są z rytuałami Bożego Narodzenia i narodzin w ogóle. Orzechy i inne „drobne” produkty spożywcze w różnych obrzędach występują w roli rekwizytów o wyjątkowej mocy performatywnej, a równocześnie jako przedmioty mediacyjne, ułatwiające kontakt z sacrum i w sposób magiczny zapewniające płodność, obfitość i bogactwo, oraz jako apotropeiony (Łeńska-Bąk, 2010, 253). 
do konkurencji o najsmaczniejsze ciasto stawały rodziny mające panny na wydaniu i młodzieńców do ożenku oraz z narracją o zaręczynach, ślubie i (niestety - o czym będzie jeszcze mowa - bezdzietnym) małżeństwie Any. Orzechy i rakija z winogron (lozovača) pojawiły się na stole także wówczas, gdy Vojko przyszedł prosić o rękę Any. Orzechami - oraz ryżem, kostkami cukru i słodkimi kuleczkami - nowożeńcy zostali obsypani po ślubie. A już w roli żony, Ana robi nalewkę z orzechów, którą obraca niby (tobože) według starego, w istocie przez siebie wymyślonego, obyczaju.

\section{Rytualne biesiady}

„Vidjela je mnogo vjenčanja. To, baš kao i sprovodi i vjerske povorke na određene blagdane, bili su važni i upadno slikoviti događaji u mjestu" (Slamnig, 1998, 328) - tym zdaniem narratorka rozpoczyna drugą część opowieści o losach Any, która jest bardziej samoobserwatorem niż osobą przeżywającą i okazującą emocje. Ślub zostaje tu wymieniony wśród innych obrzędów ważnych dla miejscowej wspólnoty (nie jednostki i nie klapy). Ana słusznie zrównuje rangę (własnego) ślubu z pogrzebem ${ }^{9}$ czy procesją kościelną, gdyż reprezentują one tradycyjne rites de passage i wymagają podporządkowania się tym samym zasadom. Na zaślubiny i na pogrzeb składa się ceremoniał jedzenia, uroczysty pochód, obrzęd płaczu, w procesji weselnej bierze udział cała grupa społeczna (cf. Freudenberg, 2009, 124-125, 133-136). W świadomości społeczeństwa pierwotnego/tradycyjnego śmierć także reprezentuje pierwiastek płodny. Ziemia (grób, czeluść) to

matka, z której rodzą się nie tylko rośliny, ale też zwierzęta i ludzie. Stąd obraz ziemi jako szafarki życia i wszelkiej płodności, jako fructodora i onesidora, stąd też podwój-

\footnotetext{
${ }^{9}$ Intrygująca jest także informacja, pochodząca od samego narratora, o jego śmierci: „Obilazak terena i zanemarenih spomenika odveo me je u Komisiju za zaštitu spomenika i konačno u turizam i u smrt" (Slamnig, 1998, 298), z której wynikałoby, że snuje swoją opowieść ,„przywrócony do życia”, ożywiony, co wpisywałoby się w wykładnię Freudenberg (2009, 116-122: „Jedzenie” jako zmartwychwstanie oraz Śmierć i zmartwychwstanie w akcie jedzenia): „«umrzeć» w języku archaicznych metafor oznacza «rodzić» i «wrócić do życia», a «wrócić do życia» - to umrzeć (zadać śmierć) i rodzić (urodzić się). (...) Pożerając człowiek wskrzesza obiekt jedzenia, sam także powracając do życia; «jedzenie» - to metafora życia i zmartwychwstania” (Freudenberg, 2009, 121). Cf. też Grgić, 2010, 271.
} 
na semantyka „nasienia” i „siewu”, żniwa (...) płodzenie i sama śmierć to formy życia wiecznego, nieśmiertelności, powrotu z nowego stanu do starego i ze starego do nowego. Śmierć nie jest nieodwracalna; wszystko, co umiera, odradza się w nowej latorośli, w rozpłodzie, w dzieciach (Freudenberg, 2009, 120-121).

Porównanie wesela i pogrzebu pojawia się w trakcie podróży poślubnej, i tu Ana czuje się bardziej jak uczestnik jakiejś przygody, zdarzenia (nawet ostatecznego), jak bierny obiekt niż podmiot i kreator wydarzeń: „osjećala je kao da je došla u onakvu nemoguću ali zanimljivu zgodu kao kad bi je nosili na vlastitom sprovodu, a ona to cijelo vrijeme pratila" (Slamnig, 1998, 329). Po ślubie Ana i Vojko, wbrew tradycji i z naruszeniem przyczynowo-skutkowego ciągu obrzędu, zostawiają weselnych gości na uczcie w domu rodzinnym pana młodego, sami zaś wyjeżdżają na miesiąc miodowy.

W społeczeństwach tradycyjnych, którym jest opisane przez Matyldę środowisko dalmatyńskie z pierwszej połowy XX w., rytuały zaślubin, podobnie jak inne rytuały przejścia, wymagają spożycia odpowiednich potraw, po pierwsze zabezpieczających przed niepożądanymi skutkami kontaktu z zaświatami i sacrum, do których dochodzi przy tej okazji, a po drugie mogących przynieść korzyści, zapewnić młodym małżonkom potomstwo i pomyślność. Wyjątkową moc performatywną, według tradycji, posiadają: mak, zboże, orzechy, groch, inne „drobiazgi” oraz miód (Łeńska-Bąk, 2010, 252). Tymczasem w domu wypoczynkowym, do którego przybywają na miesiąc miodowy, młodożeńcy zamawiają „,hladnu piletinu, miješano začinjeno sirovo povrće koje je nosilo ime jedne južnoslavenske pokrajine i francusko pjenušavo vino. Ništa od toga ne bi njoj palo na pamet, ali jela je s tekom" (Slamnig, 1998, 330). Żadna ze spożywanych potraw ,nie przyszłaby bohaterce do głowy”, gdyż są to dania nietypowe dla weselnych biesiad.

W obrzędzie weselnym należało zadbać o ziarna zbóż, kaszę, orzechy i miód oraz dania pieczone lub gotowane, poddane działaniu ognia, jednak Vojko, przedstawiciel miejscowej inteligencji, zrywa z rytualnymi działaniami i potrawami, miodowy miesiąc bez miodu (i zboża lub kaszy ${ }^{10}$ )

\footnotetext{
${ }^{10}$ Należy podkreślić, że pewne, niezbędne dla poprawnego przeprowadzenia rytuału, pokarmy pojawiły się podczas zaślubin, jednak nie zostały przez młodożeńców spożyte, nie dopełniono zatem wszystkich obrzędowo-obyczajowych czynności. Podczas weselnego
} 
skutkuje brakiem potomstwa, chorobą, śmiercią. Obowiązkową potrawą weselną w społeczeństwach tradycyjnych był kogut, jego symbolika jest ściśle związana z płodnością, a fakt piania o świcie łączono z mocą apotropeiczną i funkcją mediacyjną. Aby bezpiecznie przejść przez fazę liminalną, jednostka potrzebowała przecież przewodników i mediatorów. Slamnig nie precyzuje jednak, czy galaretka drobiowa została przyrządzona z koguta, możliwe zatem, że żadna z potraw spożytych przez Anę i Vojka w dniu ślubu nie zapewniła im magicznej skuteczności. Działań płodnościowych nie wzmocniono także poprzez działanie ognia, nowożeńcy spożywają surowe (warzywa) i chłodne (drób), tymczasem ogień (ołtarza, ogniska czy pieca) ma także „semantykę pierwiastka, który rodzi i przywraca życie" (Freudenberg, 2009, 117).

Ana jeszcze przed ślubem widziała siebie w roli tradycyjnej gospodyni domowej: nakrywającej do stołu, podającej obiad. Tę rolę próbowała realizować już w czasie miodowego miesiąca, najpierw przyrządzała kupione od staruszki grzyby, a następnie pouczona przez wtajemniczoną kobietę, która zastępując matkę, tłumaczyła jej nazwy i charakter grzybów („Ovo ti je, ćerce...”, Slamnig, 1998, 332), sama je zbierała, mając satysfakcję, że podawane mężowi jedzenie pochodzi bezpośrednio z ziemi: „sama otima zemlji hranu za Vojka” (Slamnig, 1998, 332). Ana staje się karmicielką pośredniczką w szeregu matek: matki ziemi żywicielki i „matki staruszki wiedźmy”, czyli posiadającej wiedzę, wiedzącej więcej. Mąż błędnie łączył ten pokarm z własną siłą męską, oferowaną co wieczór żonie, grzyby są bowiem symbolem długowieczności, nie zaś męskości,

obrządku, podobnie jak w innych rytuałach przejścia i podczas Bożego Narodzenia, stosowano rzucanie pokarmu (ziarna, maku, grochu, orzechów itp.) w górę jako ofiary dla dusz zmarłych, bóstw, demonów i wszelkich transcendentnych mocy aktywnych podczas obrzędu przejścia. Celem tych działań było zapewnienie uczestnikom płodności, pomyślności, obfitości i ochrony. Łeńska-Bąk twierdzi, że dzisiejszy (i obecny w powieści Slamniga) zwyczaj obsypywania po ślubie ryżem (jako drobne ziarno ma tę samą wykładnię, co zboże) nie realizuje funkcji magiczno-symbolicznych, wśród obsypujących brak zresztą świadomości takich magiczno-obrzędowych sensów, lecz wpisuje się w zjawisko amerykanizacji i pełni funkcję zabawową, dekoracyjną, efektowną. Dzisiejszy obrzęd (weselny i nie tylko) uległ desemiotyzacji i desakralizacji; z obrzędu przekształcił się w ceremonię (Łeńska-Bąk, 2010, 276-278). Trudno dociec, czy rzeczywiście w Dalmacji przed II wojną światową obsypywano nowożeńców ryżem, być może Slamnig przenosi dzisiejszy zwyczaj na tamten okres, i czy już wówczas możemy mówić o amerykanizacji. 
a jako niskokaloryczne raczej siły nie dodawały, choć zawierają białka, witaminy i sole mineralne („,On je ušali povezivao tu hranu s valstitom muškom snagom, koju je Ana dočekivala svake večeri. Pod konac mjeseca shvatila da nije zanijela", Slamnig, 1998, 332). Natomiast rozkosz ziemską symbolizują skubane przez Vojka w czasie grzybobrania poziomki, które - jak pisze Maguelonne Toussaint-Samat w Historii naturalnej i moralnej jedzenia $(2008,589)$ - zyskały sławę filtru miłości.

\section{Wymyślanie tradycji}

Pozornie tradycyjna opowieść Matyldy - która, jak deklaruje autorka, ani nie dąży do oryginalności, ani nie zamierza nadawać swoim dziełom charakteru mimetycznego, reportażowego, chce jednak wypełnić lukę, wykorzystać miejsca puste, nurty ledwie zasygnalizowane, łącząc przy tym „mnogobrojne manire” i czerpiąc z wydarzeń historycznych (Slamnig, 1998, 300) - okazuje się grą z tradycją. W przeciwieństwie do opowieści ramowej, tradycja jest tutaj naruszana i falsyfikowana. Jej bohaterka nie postępuje zgodnie z obowiązującymi rytuałami, modernizuje je i zniekształca. Być może też nie dysponuje odpowiednią wiedzą na temat kontinuum obrzędowego, w którym uczestniczy, podobnie jak Matylda (Zagorka, Zagrzebianka i kajkawka) może nie dysponować wystarczającą wiedzą na temat dalmatyńskich realiów i odpowiednim językiem, który mógłby reprezentować czakawską rzeczywistość. Bohaterowie opowieści wewnętrznej sprzeniewierzają się obyczajom już w dzień zaślubin, a następnie Ana - w sferze żywieniowej postępując zgodnie z pisarską zasadą Matyldy - zapożyczając od tradycji, tworzy własne kulinarne przepisy, które miejscowa społeczność akceptuje i uznaje za odziedziczone i zgodne z rodzinnymi rytuałami (podobnie jak Flaks założył dziewiętnastowieczny rodowód narracji ciotki, podczas gdy dzieło okazało się współczesną pułapką zastawioną na jego jedynego czytelnika). Kontynuując miejscowy zwyczaj zapraszania na tradycyjne domowe ciasto czy nalewkę orzechową, Ana wymyśla własną orzechówkę i własne ciasto. Potwierdzając swój nowy status społeczny i seksualny, paradoksalnie kontynuując, równocześnie zdradza tradycję, zamiast poddać się znanym rytuałom, modyfikuje stare lub wprowadza nowe (Jukić, 2006, 367-368). Analogicznie 
postępuje podczas imienin męża, wymyślając ,zwykłe niezwykłości”: „[m]orala je pronaći svoje obične neobičnosti” (Slamnig, 1998, 335), konsekwentnie do tradycyjnych potraw i zwyczajów dołącza własne, nowe przyprawy, wykonanie, zestawienie lub podanie. Na przystawkę proponuje tradycyjne Vojkowe szalotki (których jednak on nie zjada, pozostawiając je na inne, codzienne obrzędy) i słone sardynki, do których poda mocną winogronową rakiję, o czym nikt w mieście nie słyszał (,što nitko u mjestu nije radio", Slamnig, 1998, 335). Społeczeństwo/grupa akceptuje jednak „,nowotwory” Any, uznając je za jej rodzinny zwyczaj (,Svi su migovima i pažljivom šutnjom dali do znanja da su shvatili da je ovo neki stari običaj, koji je Ana donijela iz svoje obitelji”, Slamnig, 1998, 336). Eksperymentując, bohaterka dba, by nie przekroczyć granicy, która mogłaby wskazywać, że zrywa z tradycją. Miała pokusę nie podać zupy, jednak świadomość, że będzie to odebrane jako nadmierna ekstrawagancja, zaowocowała decyzją o powierzeniu teściowej przygotowania tej potrawy. Na deser wymyśliła wzbogacone specjalnymi dodatkami ,niedźwiedzie łapy” - ciasto mające przypominać północne kraje, w których szerzył wiarę św. Wojciech, patron Vojka. Niezwykłe ciasto wymagało zakupu nowego kuchennego wyposażenia: „Morali su otići čak u S. da kupe limene posudice i mlin za orahe” (Slamnig, 1998, 335); przykuło też uwagę spożywających, więc - jak tradycja nakazuje - Ana swój przepis podyktowała zaproszonym krewnym i znajomym. Pozornie podporządkowując się imieninowym rytuałom, Ana je unowocześnia i indywidualizuje, a w konsekwencji łamie dotychczasową i kreuje „nową tradycję” żywieniową. Do uniezwyklania imieninowych uroczystości przyczynia się także Vojko, kupując na tę okazję osobliwe napitki. Na świątecznym stole nie znalazło się nie tylko nic tradycyjnego, ale też nic lokalnego, dalmatyńskiego, śródziemnomorskiego, na danie główne Ana wybrała indyka i nerki cielęce (Slamnig, 1998, 335). Tradycja w narracji Matyldy byłaby zatem - pisze Tatjana Jukić „niby tradycją, inną tradycją", a tradycyjny dom okazuje się niestabilny:

tradiciju i povijesni kontinuitet nije ni moguće razgraničiti osim kao kontinuiranu asimilaciju graničnosti, diskontinuiteta, drugosti i tobožnjosti. S tim u skladu, fabularni materijal koji u pripovijesti o Ani naizgled pretjerano tematizira domaćičko (jelovnici, recepti...) ujedno opisuje modus operandi najšire shvaćenog doma, kao simboličkog prostora nestabilnih granica, unutar kojih se konstruira komunalni identitet. Metaforičko (i etimološko) klizanje doma prema domaćičkome, i obrnuto, odgovara zapravo klizanju koncepta 
doma, čija simbolička kartografija čas uključuje širu zajednicu i njezine institucije, a čas je isključuje, i to lokalnu zajednicu što se i sama konstituira izmjeničnim uključivanjem i isključivanjem nacionalnih, lingvističkih i regionalnih drugih (Jukić, 2006, 368).

\section{Kuchnia regionalna}

Regionalną specyfikę Matylda eliminuje z opowieści także na poziomie językowym, prowadząc narrację w standardowej sztokawszczyźnie, mimo że opisuje czakawską lokalność. Dialektami oraz potrawami i trunkami tradycyjnymi i regionalnymi są natomiast zainteresowani przyjaciele Flaksa, przy czym w kontekście jugosłowiańskim rodzi się pytanie o to, co znaczy domowe, miejscowe, regionalne (domaće). Slamnig gra wyrazem domaće, według klapy oznacza on kulinaria właściwe dla miejsca/miejscowości, ewentualnie regionu, w którym aktualnie bohaterowie się znajdują, dla karczmarki w północnej Chorwacji (okolicach Brestovlja) domaće to wszystko, co pochodzi z Jugosławii: sardynki, ser bilogorski Zdenka, szynkowa nieznanego producenta, wina słoweńskie, serbska rakija z Čačka. Na pytanie „Imate li kaj domaćega?” karczmarka odpowiada „Je, pa sve je domaće, nije iz uvoza (...). - A nisam ni ja strankinja" (Slamnig, 1998, 315). Kolejny powód do nieporozumień to regionalne nazewnictwo, po długich pertraktacjach okazało się, że lokal dysponuje domową rakiją z winogronowych wytłoczyn, tyle że przez klapę nazywana jest ona komovica, a przez lokalną sprzedawczynię žganica (w polskim przekładzie mało precyzyjna „winogronówka”). Kulinaria wykorzystane zostały przez Slamniga do narracji o lokalności i ponadlokalnej wspólnocie państwowej, którą bohaterowie ignorują. Poszukując śladów przedodrodzeniowych napisów, czyli z czasów podziału Chorwacji na różne administracyjne i kulturowo-cywilizacyjne jednostki, Flaks i towarzysząca mu klapa skoncentrowani są na tym, co regionalne i dialektalne. Poza napisami i dialektalnym bogactwem językowym, obiektem zainteresowania couleur locale są dla klapy winnice porastające wzgórza, myśl o wytwarzanym tu wspaniałym białym winie oraz znakomitych regionalnych potrawach. Podczas gdy Matylda unifikuje, Flaks pokazuje regionalne bogactwo.

Leszek Małczak, sięgając po wyróżnione przez Zygmunta Baumana (1994) wzory osobowe, w opowieści Flaksa wskazał ponowoczesne figury 
przemieszczającego się po Zagrzebiu spacerowicza, szukającego wrażeń turysty, uciekającego przed osiadłością włóczęgi, natomiast w opowieści Matyldy figury nowoczesnych pielgrzymów zmierzających do z góry wyznaczonego celu (Małczak, 2007, 266-267). Metaforę pielgrzymowania $\mathrm{W}$ opowieści wewnętrznej wzmacniają odwołania do procesji weselnych, pogrzebowych i kościelnych. W drodze do celu zjadają tyle, ile potrzeba do przeżycia, spożywanie jest częścią rytualnego kompleksu, a konsumpcji rzadko towarzyszy przyjemność, częściej powściągliwość. Włóczędzy w swoich peregrynacjach posilają się kanapkami, na wycieczki zabierają suchy prowiant (jedzenie codzienne), żywią się w gospodach, pizzeriach, restauracjach, a w czasach studenckich w stołówkach. W swym przygodnym świecie dbają o zachowanie funkcji integracyjnej żywności i marzą o potrawach regionalnych, tradycyjnych, świątecznych, jak purica s mlincima, patka, fazan u lovačkom sosu, štrukle, krvavice, češnjovke (Slamnig, 1998, 318). Co więcej, marzenia udaje się zrealizować: w swej włóczędze po Zagorju, podążając za zapachem, docierają do pieczeni z rusztu i „rzucają się"

na pečenice i senf zagrizajući u hrge kruha kakav u Zagrebu ne dobiješ. Pogledavali smo se - bilo nam je smiješno što smo najednom ušutjeli i bacili se na jelo kao Turci iz Smail-age (,,lijepijem redom vuka u planini”) (...). Glad smo brzo utažili, javila se sada želja za špricerom, za zahodom, za šetnjom (Slamnig, 1998, 325).

\section{Jak wilki}

Odwołując się do znanej sceny z eposu (1846) Ivana Mažuranicia, a wcześniej zanotowanej przez Matiję Mažuranicia w dzienniku podróży Pogled u Bosnu (1842), Slamnig kontrastuje „barbarzyńskie” zachowanie klapy z dobrymi manierami i powściągliwością konsumpcyjną bohaterów opowieści wewnętrznej. Turcy w Smail-adze reprezentują oczywiście odwiecznego wroga, porównanie do chtonicznego zwierzęcia i wskazanie na utratę kontroli wzmacnia stereotypowy portret dzikiego wschodniego barbarzyńcy, ale Turcy są także - zgodnie z romantycznymi postulatami - dziećmi natury, dlatego ich zezwierzęcenie można interpretować jako odpowiedź na postulaty Jeana-Jacquesa Rousseau. Zgodnie z wykładnią Freudenberg $(2009,115)$ zachowanie Turków i klapy jest przejawem 
zanurzenia w tradycji, ,rozdzieranie strawy to forma pierwotnego publicznego aktu jedzenia" stwach łączony z mocą fizyczną, ujawniającą się w mięśniach, które informowały o dobrym wojowniku. Wódz, chcąc zapewnić sobie największą siłę i umiejętności musiał pochłaniać ogromne ilości pożywienia. „To je postao znamen (a istovremeno i potvrda) tipične životinjske, čak i bestijalne nadmoći nad ostalim članovima zajednice" (Montanari, 2011, 82). Spożywaniu, znaturalizowanych w zagorskiej arkadii, członków klapy towarzyszy informacja o innych potrzebach fizjologicznych (nieobecnych w narracji Matyldy). Ich apetyt na konsumpcję kulinarną i seksualną, na wspólnotowość, ucieczkę do natury wydaje się nieustannie zaspokajany i zawsze niezaspokojony. W Surowym i gotowanym Lévi-Strauss pisze o bohaterach powściągliwych (powstrzymujących się zarówno od śmiechu, przełykania, jak i narzekania) i nieumiarkowanych (niepotrafiących się powstrzymać od śmiechu, szerokiego otwierania ust w czasie jedzenia, otwierania uszu czy zwieraczy, Lévi-Strauss, 2010, 139). Umiarkowanie (charakterystyczne dla bohaterów opowieści wewnętrznej) okazuje się przesadnym zamknięciem, natomiast nieumiarkowanie otwarciem wszystkich zmysłów (i otworów). Także otwarciem się na życie i odrodzenie: „Pożerając, człowiek wskrzesza obiekt jedzenia, sam także powracając do życia; «jedzenie» - to metafora życia i zmartwychwstania" (Freudenberg, 2009, 121).

\section{Wszystkimi zmysłami}

Brak sygnałów, czy Ana i Vojko czerpią przyjemność z jedzenia, niewątpliwie jednak otwarciu na pokarm nie towarzyszy otwarcie innych zmysłów, a zwłaszcza seksualnych. Do nocy poślubnej i współżycia Ana przygotowywała się na podstawie opisów i ilustracji z encyklopedii ojca, jednak akt seksualny postrzegała jako nieprzyjemny, który „trzeba jakoś

${ }^{11},[\mathrm{D}]$ la człowieka pierwotnego akt jedzenia stanowił też akt jedzenia samego bóstwa [dokonujący się w czasie eucharystii - K.P.-M.] (tj. złożenia ofiary), ale wiązało się z tym również rozszarpanie obiektu spożycia, wspólne pochłanianie jego ciała i picie jego krwi - jeżeli było to zwierzę, chleba i napoju roślinnego - jeżeli były to rośliny uprawne" (Freudenberg, 2009, 115). 
znieść, zaciskając zęby" (Slamnig, 1998, 308), to przeczucie potwierdziła noc poślubna z towarzyszącym jej bólem. Ana, współżyjąc, paradoksalnie, wyłącza zmysły, by dzięki temu spełnić małżeński obowiązek i przeżyć: „Boljelo ju je, ali voljela je Vojkovu blizinu u bilo kojem stanju. Tako je i ostalo, i nikada nije doživjela svoj vrhunac, ali svijest o tome više je spadala u znanost nego u njezin čulni život” (Slamnig, 1998, 331). Posiadając wiedzę, Ana potrafi zrealizować powinność, jednak nie towarzyszy jej spełnienie, uniesienie czy - przeciwnie - gniew i rozgoryczenie. Niedostatek zafascynowania lub odrzucenia (,,ikakvoga žara ili jetkosti”, Slamnig, 1998, 299) dostrzega Flaks w stosunku Matyldy do sztuki, ten brak emocjonalnego zaangażowania charakteryzuje także jej bohaterkę.

Flaks, przeciwnie, zaspokaja wszelkie potrzeby, łącząc przyjemność kulinarną z rozkoszą seksualną. Otwarcie na zmysłowe doznania może najpełniej oddaje kulinarno-seksualna przygoda z Anitą, rozpoczynająca i kończąca się w kuchni, w której bohater przygotowuje uzbecki pilaw, dokładnie opisując poszczególne składniki i czynności. Spożywaniu dania towarzyszy czerwone wino z Pelješca, a zakończona konsumpcja pokarmu przeradza się w konsumpcję seksualną, po czym następuje zmywanie naczyń porównane do zacierania śladów. „Obmycie” nie kończy seksualno-żywnościowych form komunikacji; wykorzystując aluzje do kształtu ciasta i do symbolicznych znaczeń składników, Anita proponuje na deser zawijaniec z orzechami: „Orehnjača. Ne bi li me zagrljio?” (Slamnig, 1998, 345).

\section{Kropla rakiji}

Wieczne zaspokajanie głodu ponowoczesnych bohaterów żarłoków nie skutkuje dolegliwościami zdrowotnymi, podczas gdy wyraźnie słabnie kondycja Vojka (lekarza) karmionego falsyfikowaną tradycją kulinarną i spożywającego „kao misnik”12 ledwie „suzu rakije”. Okresem

\footnotetext{
${ }^{12}$ Olga Freudenberg przypomina, że archaiczne rozumienie aktu jedzenia najlepiej zachowało się w, odtwarzającej obrzęd jedzenia i picia, liturgii, której punktem kulminacyjnym jest „komunia”. Chleb jest w niej uznany za baranka i Ciało Pańskie, a wino z wodą (w narracji ramowej powieści Slamniga w postaci szprycera, czyli wina z wodą sodową lub gazowaną) uchodzi za krew Chrystusa. Rosyjska teoretyczka literatury nie widzi różnicy
} 
dramatycznym okazuje się wojna, kiedy przygotowanie obiadu stanowiło wyzwanie, a to, co udało się przyrządzić, było mało pożywne, niesmaczne, właściwie niejadalne („,nejestivo dostignuće”, Slamnig, 1998, 352). W tym właśnie czasie zagrożenia życia, także z powodu braku żywności, Vojko staje się coraz bardziej wybredny: „skuše nije mogao, jaja nije smio, sol nije trošio, tražio je čudne stvari, kao kašu od posija ili kiselo mlijeko" (Slamnig, 1998, 354). Usiłując sprostać wyzwaniu, Ana łamie miejscowy zwyczaj, który gospodyniom nie pozwalał kupować bezpośrednio od przybywających z połowu rybaków, i przynosi do domu świeże morszczuki, kabryle oraz labraksy ${ }^{13}$, w zamian zanosząc rybakom przygotowane przez Vojka woreczki z lekarstwami. Troskliwy lekarz (i powściągliwy konsument) nie dostrzegł własnej choroby - bohater zaniemógł na nerki, pęcherz, woreczek żółciowy i przedwcześnie zmarł.

Kuchnia - pisał w Surowym i gotowanym Lévi-Strauss $(2010,169)$ „nie tylko wyznacza przejście od natury do kultury, ale też definiuje kondycję ludzką i wszystkie jej atrybuty, nawet te, które wydają się naturalne, tak jak śmiertelność". Grzyby nie zapewniły bohaterowi długowieczności, powściągliwość żywieniowa, a nawet aseptyczność nie uchroniły od choroby. Świat małżonków był poukładany i zrytualizowany. Ana, karmicielka, czekała na powrót męża z dokończeniem obiadu, kiedy on rytualnie zjadał codzienną porcję szalotek i wypijał kieliszek (,dvadeset suza”) mastiki (Slamnig, 1998, 335) ${ }^{14}$, ona kończyła przyrządzanie potraw, a następnie rytualnie się przebierała. Antyseptyczny napitek i przekąska wydają się dobrą metaforą (nie)zmysłowego życia Any i Vojka.

treści powszedniej czy religijnej w akcie jedzenia przy domowym stole i liturgii kościelnej, a paralelizm tożsamych zjawisk w życiu powszednim i w świątyni traktuje jako dowód na to, że obyczaj powszedni jest nie mniej od religii konserwatywny i rudymentarny (Freudenberg, 2009, 107-110). W narracji wewnętrznej powściągliwe spożywanie alkoholu porównane jest właśnie do zachowania kapłana w czasie Mszy św. („pili kao misnik”, Slamnig, 1998, 331).

${ }^{13} \mathrm{~W}$ oryginale: osliće, kanjce, smudut (Slamnig, 1998, 354-355), w przekładzie: strzępiel, wątusz, łososiookoń (Slamnig, 1976, 109).

${ }^{14}$ Szalotki, jak czosnek, mają działanie bakteriobójcze (chorw. ljutike - czyżby nazwa przysmaku okazała się złowróżbna?) podobnie jak mastika, czyli rakija z mastyksem, trunek o działaniu przeciwgrzybiczym i bakteriobójczym. 


\section{Nieustająca żarłoczność}

Chaotyczny, przygodny i nieuporządkowany świat żarłocznej klapy okazuje się dla bohaterów bardziej sprzyjający. Jakby Slamnig stawał po stronie nieuładzenia, natury i tradycji niefalsyfikowanej. Narrator i bohater chętnie uczestniczy w ludowych świętach, na których serwowane są miejscowe, tradycyjne potrawy, należy do nich (trzykrotnie wspomniany w powieści) symbolizujący harmonię wszechświata bażant, ptak, który zerwał z niebem i oddał się ziemskim przyjemnościom. Bażant jest też symbolem życia w biedzie i niepewności, ale wolnego od ograniczeń (Chevalier, Gheerbrant, 1994, 153). Nieprzypadkowo zatem na początku utworu klapa spotyka się w gospodzie „Pod dwoma bażantami”, a spożywanie bażanta w sosie nosi znamię chwili o historycznym znaczeniu (Slamnig, 1998, 343).

Inna symboliczna potrawa spożywana przez ponowoczesnych bohaterów to regionalna zupa z podrobami, która z przystawki (predjelo) zamieniła się $\mathrm{w}$ danie główne, pièce de resistance, gwóźdź programu. Danie z tego, co pochodzi z samego środka zjadanego zwierzęcia, z wnętrza łańcucha pokarmowego. Flaks i jego przyjaciele zajadają się podrobami, gulaszami, kaszankami, sercami i żołądkami, jedzą wnętrzności, o których narracja Matyldy nawet nie wspomina. Jednak gospodska (pańska, wysoka) i powściągliwa (jak kapłan sprawujący mszę) kultura domu lekarskiego, przegrywa z popularną, a misnik z Turkami ze Smail-agi.

\section{Konkluzje}

Kulinarny system semiotyczny, jak pokazała przeprowadzona analiza, jest szczególnym wyrazem kultury danego społeczeństwa, które w zależności od okoliczności sięga po określone warstwy tradycji przechowywane w „spiżarni” z jedzeniem. Narracja Matyldy pokazuje społeczeństwo, w którym pożywienie to sfera z jednej strony zamknięta, kobieca i domowa, a z drugiej, kiedy następuje jej „uspołecznienie” towarzyszące świątecznemu biesiadowaniu w gronie szerszej rodziny i znajomych, stająca się przestrzenią żeńskiej rywalizacji. Narracja Flaksa dotyczy społeczeństwa przygodnego, otwartego, w którym kuchnia nie jest sferą zamkniętą dla 
mężczyzny, a konsument ma skłonności do „wielkiego żarcia”, czerpiąc z niego różnorodne przyjemności. Oba wątki powieści poprzez kulinaria mówią o dialogu starego i nowego, tradycji i współczesności. Można jednak postawić śmiałą tezę, ale znajdującą uzasadnienie w powyższym wywodzie, że paradoksalnie to ponowoczesny nomada ceni i pielęgnuje tradycję oraz czerpie z niej przyjemność, podczas gdy zadomowiony, nowoczesny pielgrzym sprzeniewierza się jej, co łączy się z brzemiennymi skutkami. Ana, pozornie wpisując się w tradycję, zrywa jej ciągłość, podczas gdy Flaks i jego klapa dbają o continuum historii, na różne sposoby próbując ją ocalić od zapomnienia (dokumentowanie wydarzeń, przechowywanie pamiątek; rozprawa naukowa poświęcona zabytkom piśmiennictwa; upodobanie do tradycyjnych potraw). Kulinarny kod został wykorzystany także w metatekstualnych i internarracyjnych strategiach zamykających powieść Slamniga. Detektyw Flaks, poszukujący sensu love story Matyldy - zgodnie z wyznacznikami gatunku - na koniec odkrywa, że dał się nabrać na deklaracje narratorki o nieobecności wątków autobiograficznych i że to on sam znajduje się w centrum jej autorskiego zainteresowania. Swoje odkrycie wyraża w kulinarno-seksualnej metaforze: „Tu me je teta skuhala (...) ja sam za nju prava piletina” (Slamnig, 1998, 384). „Ugotowany kurczak" kończy opowieść i wybiera przestrzenną ewazję (Flaker), uciekając w idylliczno-arkadyjską przestrzeń chorwackiego Zagorja.

\section{Literatura}

Bauman, Z. (1994). Ponowoczesne wzory osobowe. W: Z. Bauman. Dwa szkice o moralności ponowoczesnej. Warszawa: Instytut Kultury, s. 7-39.

Chevalier, J., Gheerbrant, A. (1983). Rječnik simbola: mitovi, sni, običaji, geste, oblici, likovi, boje, brojevi. Przeł. A. Buljan, D. Bučan, F. Vučak, M. Vekarić, N. Grujić. Zagreb: NZMH, Mladost.

Donat, B. (1978). U susret drugoj polovici hrabrosti. W: Brbljava Sfinga. Kronika hrvatskog poratnog romana. Zagreb: Znanje, s. 133-137.

Douglas, M. (2007). Ukryte znaczenia. Wybrane szkice antropologiczne. Przeł. E. Klekot. Kęty: Wydawnictwo Marek Derewiecki.

Flaker, A. (1983). Proza u trapericama. Zagreb: Sveučilišna naklada Liber.

Freudenberg, O. (2009). Semantyka kultury. Przeł. A. Pomorski. Kraków: Universitas. Grgić, K. (2010). Slamnigov postmoderni bijeg. „Dani Hvarskoga kazališta: Građa i rasprave o hrvatskoj književnosti i kazalištu”, vol. 36, nr 1, s. 262-288. 
Jukić, T. (2006). Zelene, gorke, namještene: povijest (i) granice u Slamnigovoj „Boljoj polovici hrabrosti”. W: Čovjek, prostor, vrijeme. Književnoantropološke studije iz hrvatske književnosti. Red. Ž. Benčić, D. Fališevac. Zagreb: Disput, s. 367-388.

Kirshenblatt-Gimblett, B. (1999). Playing to the Senses: Food as a Performance Medium. „Performance Research”, vol. 4, issue 1, s. 1-30. http://www.nyu.edu/classes/bkg/issues/food-pr6.htm. 2.09.2015.

Lévi-Strauss, C. (2008). Trójkąt kulinarny. W: Antropologia ciała. Zagadnienia i wybór tekstów. Red. M. Szpakowska. Przeł. S. Cichowicz. Warszawa: WUW.

Łeńska-Bąk, K. (2010). O pokarmach, smakach i utraconych znaczeniach. Opole: Wydawnictwo Uniwersytetu Opolskiego.

Małczak, L. (2007). O nowoczesnych i ponowoczesnych wzorach osobowych $w$ „Lepszej polowie odwagi" Ivana Slamniga. W: Nasza środkowoeuropejska ars combinatoria. Red. K. Pieniążek-Marković, G. Rem, B. Zieliński. Poznań: Wydawnictwo Naukowe UAM, s. 265-273.

Milanja, C. (1996). Hrvatski roman 1945.-1990. Zagreb: Zavod za znanost o književnosti FF.

Milanja, C. (2001). Hrvatska književnost i postmoderna na primjeru Slamnigova roma$n a$, ,Književna revija”, 1-2, s. 42-48.

Montanari, M. (2011). Hrana kao kultura. Przeł. A. Grbac, V. Papić, P. Petrač, I. Sršen. Zagreb: Sandorf.

Nemec, K. (2003). Povijest hrvatskog romana od 1945. do 2000. Zagreb: Školska knjiga.

Slamnig, I. (1976). Lepsza połowa odwagi. Przeł. A. Dukanović. Warszawa: PIW.

Slamnig, I. (1998). Bolja polovica hrabrosti. W: Relativno naopako. Wyb. i przedmowa P. Pavličić. Zagreb: Mozaik knjiga, s. 281-386.

Tadić-Šokac, S. (2009). Metatekstualni postupci u romanu „Bolja polovica hrabrosti” Ivana Slamniga. ,Fluminensia”, 21, nr 2, s. 91-113.

Toussaint-Samat, M. (2008). Historia naturalna i moralna jedzenia. Przeł. A.B. Matusiak, M. Ochab. Warszawa: WAB. 